\title{
APPLICATION OF HIGHER ORDER THINKING SKILLS (HOTS) IN TEACHING AND LEARNING THROUGH COMMUNICATION COMPONENT AND SPIRITUAL, ATTITUDES AND VALUES COMPONENT IN PRESCHOOL
}

\author{
Suppiah Nachiappan', Afiqah Ahmad Damahuri², Charles Ganaprakasam \\ \& Sandra Suffian ${ }^{4}$ \\ Faculty of Human Development, Sultan Idris Education University, \\ 35900 Tanjong Malim, Perak, Malysia. \\ suppiah@fppm.upsi.edu.my ${ }^{1}$,d062049@siswa.upsi.edu.my², \\ ganaprakasamcharles@gmail.com ${ }^{3}$, sandrasuffian@gmail.com ${ }^{4}$
}

\begin{abstract}
The main aim of this study is to observe the application of Higher Order Thinking Skills (HOTS) in teaching and learning through Communication component and Spiritual, Attitudes and Values component in preschool. This study was conducted using qualitative method and also using Daily Lesson Plan (DLP) of a practicum teacher at the kindergarten that was located in Ipoh, Perak. This study also uses Hermeneutics Method. This method is used to interpret the DLP texts that were written by the practicum teacher. A total of 13 Daily Lesson Plans from the week nine until the fifteenth week were reviewed by focusing on Communication component that was Malay language and English and also Moral Education for the Spiritual, Attitudes and Values component. The researcher analyses the Higher Order Thinking Skills in teaching and learning in preschool through Communication component and Spiritual, Attitudes and Values component. It was found that teachers uses only three levels of Higher Order Thinking Skills, i. e. application, analysis and evaluation in teaching and learning. However, only twice the level of thinking, created was used by teacher. Teaching and learning that was carried out did not include an attractive teaching aids. As a way to overcome the problem of teachers in teaching and learning, practical teacher must have wide knowledge through extensive reading in order to implement the various activities and more interesting.
\end{abstract}

Keywords: higher order thinking skills, hermeneutics method, communication component, spirituality, attitudes and values component

\section{INTRODUCTION}

Early Childhood Education is important as the proper upbringing from small will be able to produce a holistic child with qualities in the future. In Malaysia, preschool education happens to be the basic preparation for a child to get into primary school. The child's potential is perfected from the aspects of development, to master basic skills and encourage positive attitude.

There are two levels of early childhood education in Malaysia according to the children's age. The first level is Taska for children aged 4 and below while the second level is Tadika for children aged from 4 to 6 . Schools built by the Ministry of Education are known as preschools. These preschools are responsible for children from 4 to 6 to be taught with proper upbringing that gets the child's development growing well in terms of physical, language, cognitive, socioemotions and spiritual attributes according to their ages in a safe, sound and happy surrounding.

According to the National Standard Preschool Curriculum - NSPC (MOE, 2001), the age levels from 4 to 6 years old are the formative levels for children. Preschool curriculum was drafted to encourage child's potential in a whole and integrated aspect to build their mind and creativity, 
cultivate and practice based on religion and moral values, strengthen and stabilise emotional and physical nourishment in preparation for community-based life and face formal education in primary school.

NSPC which was introduced in 2010 gives the opportunity to all children aged between 4 to 6 years old so that they can develop their potentials in a whole and integrated in physical, emotional, intellectual, spiritual and social aspects. There are six main elements existing in NSPC, namely Communications, Spirituality, Attitude and Values, Humanity, SelfEsteem, Physical and Aesthetics as well as Science and Technology. In this academic writing, it is described on how a preschool teacher stresses HOTS into teaching and learning process in accordance to the Communication component as well as Spirituality, Attitude and Values.

\section{Higher Order Thinking Skills (HOTS)}

Definition to HOTS according to MOE (2015), is the ability to apply knowledge, skills and values in making sense and reflect to solve problems, make decisions, innovate and create something. Malaysian Education Development Plan (MEDP) 2013-2025 happens to be a longterm strategic plan that is aimed at enhancing the quality of education nationwide within the next 13 years with the implementation of comprehensive education transformation.

To achieve this, all parties need to support each other and play their roles. Teachers in particular need to equip themselves with new knowledge and skills as well as new teaching and learning practices relevant to 21 st century developments and needs, thinking skills across all disciplines within children should be given priority. Teacher and student's thinking skills, especially in the context of HOTS, is a priority in determining success of education transformation as outlined in MEDP 2013-2025 (MOE, 2015).

In order to implement HOTS effectively, the resource materials must be structured so that they can realize the application of knowledge, skills and values that students acquire to help them understand, reflect and solve problems, make decisions, innovate and create. Compiling of resource materials should provide an opportunity for students to interact with the material through challenging learning activities that students apply HOTS (MOE, 2014).

Table 1: Thinking Levels in HOTS (MOE, 2016)

\begin{tabular}{lll}
\hline THINKING LEVELS & EXPLANATION \\
\hline Apply & $\bullet$ & $\begin{array}{l}\text { Use knowledge, skills and values in different situations to } \\
\text { do things }\end{array}$ \\
Analyse & $-\begin{array}{l}\text { Convincing the information to a small section to understand } \\
\text { more deeply and in the interrelationships between the } \\
\text { sections }\end{array}$ \\
Evaluate & $\begin{array}{l}\text { Make judgments and decisions using knowledge, } \\
\text { experience, skills and values as well as justification }\end{array}$ \\
Create & $\begin{array}{l}\text { Generate creative or innovative ideas or products or } \\
\text { methods }\end{array}$
\end{tabular}


Higher Order Thinking Skills (HOTS) is defined from the invention by Ciardiello (2000). He emphasized that readers operating on higher cognitive domains in thinking skills demonstrate that they are able to produce significant uniqueness in communication, different ideas and apply critical and creative knowledge. King (2002) further defined the high level of cognitive processing such as inferring, drawing conclusions, synthesis ideas, generating hypotheses, comparing and differentiating, analyzing and evaluating alternatives.

\section{Critical Thinking Skills}

Angelo and Cross (1995) argue that critical thinking skills are associated with higher level skills such as analysis, synthesis, identifying and solving problems, making inferences or conclusions and evaluating things.

According to MOE (2016), critical thinking skills are the ability to evaluate ideas in a logical and rational way to make appropriate judgments using reasonable grounds and evidence. According to Beyer (1995), critical thinking skills is to make decisions with reasonable justifications. Beyer (1995) sees critical thinking as a specific criterion used to determine the quality of something, from simple to complex.

Critical thinking skills can be summarized as the process of using the mind to find meaning and understanding of things, exploring various possibilities, making decisions, solving problems, and making reflections on the process of self-thinking (Wan Hasmah \& Nur Munirah, 2013). Discipline and self-control as well as correct thinking are needed in the thinking process.

It can be concluded that one of the key skills to be mastered by students is critical thinking. Through this skill, it can produce students who are rational and wise in making decisions or solving problems.

\section{Creative Thinking Skills}

According to MOE (2016), creative thinking skills are the ability to create or create something new and evaluate by using imaginative imagery naturally as well as unconventional thinking. Creative thinking skills can be defined as the skill of using the mind to produce something new (Wan Hasmah \& Nur Munirah, 2013).

The processes involved are modifying skills, providing explanations, linking and making comparisons. According to Wan Hasmah and Nur Munirah (2013), the goal is to enable students to explore various possibilities and to stimulate students to produce something new that is either subjective, abstract or an idea.

MOE (2001) defines creative thinking skills as the ability to digest and produce generative ideas. The idea will come about through a combination of new ideas. Among the key features of the creative thinking process are as follows:

- Ability to imagine and create something new.

- Ability to accept change.

- Thinking open and flexible.

- Like something good. 
- Working strong and always looking forward.

- Ready to accept changes.

Creativity and creative thinking become daily events (Richards, 2006) in the lives of young children, often known as little creativity (Craft, 2003; Kaufmann, 2003). According to NACCCE (1999), talking about "generative thinking and evaluation" and suggesting that "creative thinking always involves some critical thinking", while Lipman (2003) believes these two ideas are interdependent.

Sternberg (2003) defines creative thinking as "new thinking and generates valuable ideas". Sternberg uses the term "something new" from "authenticity" is important in explaining that to be considered creative, the idea of a person does not necessarily imply the thought that no one has ever done before. On the other hand, creative thinking is a new thought for individuals, not necessarily for society as a whole, what matters when looking at the creative thinking of a child.

Another key idea along with both the definitions of Sternberg (2003) and NACCCE (1999) is the value perception. It has two implications. First, it sees creative thinking as social and second, it highlights the relationship between creative thinking and both thought-critical and problem-solving method (Hiroko, Robson, Greenfield \& Hargreaves, 2012).

Sternberg (2003) identifies some of the key decisions underlying creative thinking:

- Redefine the problem.

- Analyse your own ideas.

- Sell your ideas.

- Knowledge is a double-edged sword.

- Overcoming obstacles.

- Take smart risk.

- Willingness to grow.

- Trust yourself.

- Ambiguity tolerance.

- Find what you like to do and do it.

- Allow time.

- Allow errors.

\section{RESEARCH OBJECTIVES}

1. Identify how HOTS are applied in preschool teaching and learning through Communication Component.

2. Identify how HOTS are applied in teaching and learning preschool through Spiritual, Attitude and Values Component.

\section{RESEARCH METHODOLOGY}

The Hermeneutic method is used to understand the interaction of teachers with their students, especially with regards to the teaching and learning process in the classroom (Loganathan, 
1992). In the process of understanding this fact, the teachers will record the interactions in the classroom and transcribe the recording into text form. They will then conduct a research on the text using the Hermeneutics method to obtain a better picture on the teaching and learning process in the classroom.

The interpretation of meaning is done through the process of on topretation, in other words the understanding derived from a context from external reading to the internal structure of the researched text.

The Hermeneutic method is capable of reaching a further horizon compared to normal interpretation theories, as this method includes the interpretation of information which is external and internal in a text. Loganathan (1992) states that the Hermeneutic method is a form of scientific research method due to the fact that it attempts to find the truth through rational of human thinking. He explains that the science of Hermeneutics is a solution to the process of understanding the behaviour of mankind.

The Hermeneutic method can be interpreted as human behaviour in order to achieve a deeper understanding on the process of interaction among mankind. The aspect of understanding human behaviour is a challenging task for this method. It is a branch of qualitative research which is descriptive.

This method prioritizes the interpretation of text in a socio-cultural and historical context by exposing the internal meaning in the research text. A meaningful prior experience on an event or incident is to be remembered directly or indirectly. Therefore, the Hermeneutics method involves the identification of meaningful information which is then used to generate themes and categorizations from a collection of texts (Suppiah, 2003).

This research is done using the Hermeneutics method to conduct this study. This study was also carried out using basic qualitative research, which is analysing the data contained in DLPs from a private kindergarten located in Ipoh. This study also involves a practical teacher undergoing practicum training at the school. This DLPs analysis is read, scrutinized and reviewed to identify the presence of HOTS using Hermeneutics analysis in the form of text interpretation. The results obtained after examining the DLPs will be interpreted using Hermeneutics method.

The sample of the study to be used during the study is composed of DLPs which has been written by the teacher during the practicum training in the Kindergarten. This study procedure involves Hermeneutics analysis which can be implemented through the steps in analyzing the DLPs written by the teacher.

\section{RESEARCH FINDINGS}

\section{Research Question 1:}

How is HOTS implemented in teaching and learning through the Communication Component?

Based on the DLPs interpretation of Communication Component, namely Malay and English, researchers found that teachers had applied HOTS elements in each teaching step, starting with 
the set induction, step 1, step 2, step 3 and closing. Researchers have identified HOTS elements in 5 Malay DLPs, starting from weeks 9, 11, 12, 13 and 15 and as for the English DLPs is from weeks 9,11 and 13.

Based on Malay DLPs in 'Day and Time' topic, the researchers find teachers using less attractive teaching aids (TA). In the set induction, the teacher carries a box containing a small calendar and the children try to predict the contents of the box. In this situation, the researcher finds students using the HOTS element, identifying by predicting the contents of the box that the teacher brings. In teaching sessions, teachers only use word cards and photo cards as TA. Teachers are found to be using HOTS elements by explaining to students about pictures of activities by day of the week. The teachers also encourage students to think about their activities over the weekend and share opinions with other friends. Through 'Arrangement' activities, researchers find students using HOTS elements in making decisions when pasting word day cards in sequence.

In the 'Country and Celebration' topic, through the Malay DLPs, the researchers find teachers using technology and ICT as TA, which is for the use of video and slide shows through laptops. Students are asked to listen to a festive video by closing their eyes and guessing the song. Through this activity, there is a HOTS element that is applied by the teacher, which is analysing. Students need to identify festive songs in Malaysia with the celebration's name. In the 'Magic pocket' activity, the students were found to be using the HOTS element, namely applying and analysing. Students can use their knowledge and can differentiate the correct pocket apron and match with selected holiday photo cards. After review, the HOTS elements are present in each step for this DLPs, to apply and analyse. However, there is only one element of HOTS, evaluating in step 3, that students are using their knowledge and skills in choosing the right answer when answering the training questions.

Next, in the English DLPs under the topic of 'Days \& Time', there is the use of technology and ICT, the 'Day of the week' song video. There is a HOTS element identified in the singing activity performed. At first, students did not know how to sing the song. However, after listening to the teacher singing, the student can apply by singing the song with the teacher. In the next activity, the teacher uses the flash card quickly and the student should guess the word on the flash card. Students were found to be using the HOTS element, which is analyzing, which is to identify the word on the flash card. The next activity is the 'Who First?' activity. Students are required to attach word cards day by number in the place provided on the whiteboard. Students were found to be using the HOTS element, namely applying, using the knowledge in past words of day cards in orders 1 to 7 correctly.

In the topic of 'Country \& Celebration', teachers show photo slides and words (Malaysia, Indian, Gawai day, Chinese New Year, Christmas and Hibiscus). The researcher found that there is a HOTS element used by students, which is analyzing. Students can answer questions by explaining the differences of celebrations celebrated in Malaysia according to their knowledge. In the 'Spell It Right' activity, there is a HOTS element used by the teacher. Before the student did the activity, the teacher first had a demonstration. Students focus on demonstrations that teachers did. When conducting the activity, there is a HOTS element used by students, which is analyzing. The students need to identify and complete the missing words. There are also HOTS elements when students practice. Before doing the exercises, the teacher explains the instructional questionnaire to the students so that they can understand the questions better. Through that step, teachers are found to be using the HOTS element, which is analyzing. 
When responding to the training questions, the students use the HOTS element, which is applied, using the knowledge in solving the problem.

\section{Research Question 2:}

How High Order Thinking Skills (HOTS) are applied in teaching and learning through Spiritual, Attitudes and Values Component?

Based on the interpretation of DLPs for Spiritual, Attitude and Values Component on Moral Education, researchers found that teachers were applying the HOTS element in each teaching step, starting with the set induction, step 1, step 2, step 3 and closing. The researchers identified the HOTS element in 5 Moral Education DLPs from weeks 9, 11, 12, 13 and 15.

Through the Moral Education DLPs, in the topic of 'People and Useful Machines', the researchers found that teachers did not use any interesting TA. Teachers only perform 'draw and tell' activities in telling stories about 'Mary'. However, through this activity, the researchers found that there are HOTS elements used by teachers, which are analyzing. The teacher gives an explanation to the students about the story of 'Mary'. In addition, there are also HOTS elements, which are evaluated by teachers. The teacher talks with the students about the moral values found in the story that the teacher has to tell. Students were also able to use the HOTS element, which is to assess. Children can give suggestions on moral elements than stories that teachers tell.

In the topic of 'I visit my friends during festivals', teachers use festive videos as TA. The teacher opens a celebration video and asks students to close their eyes when they hear the sound from the video. Researchers find that teachers use the HOTS element, which is analyzing, asking students to predict the sound of the festive video they hear. Teachers also use the HOTS element to evaluate, which is to discuss with the student about the practices that should be performed during the festival, namely visiting the family. Children were able to explain their knowledge of special food for the festivities. Through this activity, the researcher found that there is a HOTS element, which is the analysis used by the students. Teachers also use the HOTS element, which is to apply by demonstrating a sample of the completed card for students. After that, children are required to make their own holiday cards. Students are found to be using HOTS elements to create by designing their own festival cards with their creativity. After completing a holiday card, students can display the festival card results in front of the class.

\section{DISCUSSION}

Based on the previous interpretations and descriptions, it has shown the application of HOTS elements in teaching and learning process by the practicum teachers in preschool. The presence of HOTS elements in DLPs proves that the teacher is trying to apply knowledge through the level of thought by each student. According to MOE (2016), there are four levels of HOTS thinking, namely applying, analysing, evaluating and creating. HOTS emphasises the formulation of NSPC. It is explicitly stated that teachers can translate into teaching and learning to stimulate structured thinking and focus on students (MOE, 2016). 
Based on the previous interpretations and descriptions, it has shown the application of HOTS elements in teaching and learning of practicum teachers in preschool. The presence of HOTS elements in the DLPs proved that the teacher tried to apply knowledge through the level of leadership. The findings of the study shows that practicum teachers often used the three elements of HOTS, namely applying, analysing and evaluating the writing of Communication Component in DLPs for Malay and English. The HOTS elements are found in every step of the teaching and learning of practicum teachers starting from set induction, step 1, step 2, step 3 and closing. Practicum teachers do not use HOTS elements in teaching and learning for Malay and English. Here are some of the verbs used by the practicum teachers in teaching and learning for Communication Speech. For the HOTS element, apply, the verb used is to point out the way, use and explain. The verbs for HOTS elements analysing the used are describing, displaying and testing. In the HOTS element, evaluate, the verb used is the decision, assessment and discussion of each student. According to MOE (2016), there are four levels of HOTS namely applying, analysing, evaluating and creating. HOTS is a matter of emphasis in the formulation of NSPC. It is stated that teachers can translate into teaching and learning to stimulate structured thinking and focus on students.

In the Moral Education DLPs, the researchers found that there are four elements of the HOTS, namely applying, analysing, evaluating and creating. The HOTS elements are found in every step of teaching and learning starting from the set induction, step 1, step 2, step 3 and closing. However, the creation of HOTS elements by the practicum teacher took place twice. The researcher found that practicum teachers used HOTS elements to create set induction, which is to generate students' thinking skills by asking the meaning of the word such as brave, grateful and diligent. In addition, the HOTS element is found in step 2 of learning, that is, students form their own holiday cards. Here are some of the verbs used by the practicum teachers in teaching and learning for Spiritual, Attitude and Values Component. For the HOTS element, apply, the verb used is to point the way, implement and solve the problem. The verbs for the HOTS element, the analysis used is to describe, evaluate and predict. In the HOTS element, evaluating, the verb used is to discuss, conclude and assess.

\section{CONCLUSION}

Overall, the application of HOTS in teaching and learning in preschool based on Communication Component and Spiritual, Attitude and Values Component is indeed there. Through the DLPs, practicum teachers have implemented HOTS elements well but they need to be improved. In addition, there are some problems that occur in writing DLPs of practicum teachers. To solve the problem, some suggestions have been given. It is hoped that all the explanations given in this study will answer an unclear question regarding the application of HOTS elements in teaching and learning in preschools based on Communication Component as well as Spiritual, Attitudes and Values Component.

\section{REFERENCES}

Angelo, T. A., \& Cross, P. (1995). Classroom Assessment Techniques: A Handbook for College Teachers, 2nd edition.

Beyer, B. K. (1995). Critical Thinking. Bloomington IN: Phi Delta Kappa Educational Foundation, Eastback No. 385. 
Ciardiello, A. V. (2000). Student questioning and multidimensional literacy in the $21^{\text {st }}$ century. The Educational Forum, 64(3), 215-222.

Craft, A. (2003). 'Creative thinking in the early years of education', Early Years, 23(2):143-54.

Hiroko Fumoto, Robson, S. Greenfield, S. \& Hargreaves, D. J. (2012). Young Children's Creative Thinking. London: SAGE Publications Ltd.

Kaufmann, G. (2003). 'What to measure? A new look at the concept of creativity'. Scandinavian Journal of Educational Research, 47(3): 235-51.

Ministry of Education. (2001). Dokumen Kurikulum Standard Prasekolah Kebangsaan. Kuala Lumpur: Bahagian Pembangunan Kurikulum.

Ministry of Education. (2014). Elemen KBAT Dalam Kurikulum. Kuala Lumpur: Perpustakaan Negara Malaysia.

Ministry of Education. (2015). Kurikulum Standard Prasekolah Kebangsaan. Putrajaya: Bahagian Pembangunan Kurikulum.

Ministry of Education. (2016). Kurikulum Standard Prasekolah Kebangsaan. Putrajaya: Bahagian Pembangunan Kurikulum.

King, A. (2002). Structuring peer interaction to promote high-level cognitive processing. Theory into Practice, 41:33-39.

Lipman, M. (2003). Thinking in Education. Cambridge: Cambridge University Press.

Loganathan, K. (1992). Hermeneutic analysis of discourse. Thiruvananthapuram: International School of Dravidian Linguistics.

National Advisory Committee on Creative and Cultural Education (NACCCE). (1999). All Our Futures: Creativity, Culture, and Education. London: DfEE.

Richards, R. (2006). 'Frank Barron and the study of creativity: A voice that lives on'. Journal of Humanistic Psychology, 46(3): 352-70.

Stenberg, R. J. (2003). 'Creative thinking in the classroom', Scandinavian Journal of Educational Research, 47(3): 325-38.

Suppiah, N. (2003). Cognitive processes in essay writing through hermeneutics analysis. Minden: Universiti Sains Malaysia (Unpublished doctoral dissertation).

Wan Hasmah Wan Mamat \& Nur Munirah Teoh Abdullah. (2013). Kemahiran Berfikir Kritis dan Kreatif. Kuala Lumpur: Dewan Bahasa dan Pustaka. 